\author{
Mariola Tracz \\ Zakład Dydaktyki Geografii \\ Instytut Geografii \\ Akademia Pedagogiczna, Kraków
}

\title{
O niektórych kryteriach doboru treści nauczania do podstawy programowej i programu nauczania z podstaw przedsiębiorczości
}

Przemiany polityczno-społeczne zapoczątkowane w Polsce w 1989 r. oraz postępujący proces globalizacji gospodarki na świecie stawia coraz wyższe wymagania w zakresie wiedzy i umiejętności dla osób podejmujących pracę zawodową. Istnieje silna potrzeba społeczna przygotowania młodego człowieka do funkcjonowania w dynamicznie zmieniającej się gospodarce wolnorynkowej i równocześnie tworzenia jej podstaw w kraju.

W procesie kształcenia uczeń powinien mieć zatem sposobność zdobywania wiedzy i umiejętności o mechanizmach funkcjonowania gospodarki w ujęciu lokalnym, regionalnym i globalnym oraz kształtowania postaw sprzyjających podejmowaniu wyzwań stawianych przed nim w życiu zawodowym m.in.: ryzyka, etycznego postępowania w działalności gospodarczej, asertywności itp., określanych jako ,postawy przedsiębiorczości”.

Pierwsze próby wprowadzenia do szkół średnich tej tematyki w Polsce miały miejsce na początku lat dziewięćdziesiątych XX wieku. Realizowane były pilotażowo dwa programy brytyjski - enterprise education Fundacji SEED i amerykański - Junior Achiavement (Sielatycki 1993). Programy te różniły się celami kształcenia i zakresem treści nauczania. Program amerykański główny nacisk kładł na zdobywanie przez uczniów praktycznej wiedzy ekonomicznej, a brytyjski w większym stopniu służył kształtowaniu postaw aktywności i czynnego działania młodego człowieka w poszukiwaniu pracy. Równocześnie w kilkunastu szkołach powstały klasy o profilu „menedżerskim”, gdzie w oparciu o autorskie programy nauczania uczniowie zdobywali wiedzę i umiejętności o funkcjonowaniu gospodarki wolnorynkowej i prowadzeniu własnej działalności gospodarczej.

W 2002 r. Ministerstwo Edukacji Narodowej i Sportu obligatoryjnie wprowadziło do nauczania w szkołach ponadgimnazjalnych różnego typu (liceum ogólnokształcące, liceum profilowane, technikum, szkoły zawodowe) nowy przedmiot o nazwie podstawy przedsiębiorczości.

\section{TREŚCI NAUCZANIA Z PODSTAW PRZEDSIĘBIORCZOŚCI W PODSTAWIE PROGRAMOWEJ I PROGRAMACH NAUCZANIA}

Podstawa programowa określa w sposób ogólny cele i zadania, treści nauczania oraz osiągnięcia, które powinny być realizowane $\mathrm{w}$ ramach przedmiotu podstawy przedsiębiorczości. Wśród zapisanych w podstawie celów kształcenia dla liceum ogólnokształcącego, liceum profilowanego i technikum, cztery z nich odnoszą się do dziedziny poznawczej (poznanie mechanizmów funkcjonowania gospodarki rynkowej, poznanie roli państwa i prawa 
w gospodarce rynkowej, poznanie zasad funkcjonowania gospodarki europejskiej i światowej, poznanie podstawowych zasad podejmowania i prowadzenia działalności gospodarczej w różnych formach) oraz cztery do dziedziny wychowawczej (kształtowanie postawy rzetelnej pracy i przedsiębiorczości, kształtowanie umiejętności aktywnego poszukiwania pracy i świadomego jej wyboru, rozwijanie zainteresowania podejmowaniem i prowadzeniem działalności gospodarczej) [Dz. U. nr 14,2002].

$\mathrm{Z}$ kolei treści nauczania zawierają się $\mathrm{w}$ trzech grupach tematycznych:

- $\quad$ z dziedziny ekonomii; na 22 hasła ujęte w podstawie programowej 14 dotyczy zagadnień działalności gospodarczej, np. funkcjonowanie rynku i gospodarki rynkowej, funkcjonowanie giełdy papierów wartościowych,

- $\quad z$ marketingu i zarządzania, np. planowanie procedury podjęcia działań,

- $\quad$ z psychologii, np. mocne i słabe strony własnej osobowości, samoakceptacja, asertywność.

Natomiast osiągnięcia zapisane w podstawie programowej odnoszą się do różnych kategorii. Niektóre $\mathrm{z}$ nich nie mają odpowiednika zapisanego w celach i treściach nauczania, dotyczy to osiągnięcia: „wskazanie korzyści i zagrożeń wynikających ze współpracy międzynarodowej, w tym integracji Polski z Unią Europejska oraz globalizacji gospodarki”. Występuje dwukrotnie powtórzenie tego samego osiagnnięcia - obliczanie wyniku finansowego przedsiębiorstwa na prostych przykładach, obliczanie prostych przykładów dotyczących wyniku finansowego przedsiębiorstwa.

Analiza zapisu celów i treści kształcenia zawartych w wybranych programach tego przedmiotu, zatwierdzonych przez MENiS do użytku szkolnego, wskazuje na znaczne ich zróżnicowanie w zakresie wyznaczonych celów, treści nauczania i osiągnięć.

Cele z dziedziny poznawczej są znacznie rozbudowane, opisane w formie celu ogólnego lub celów szczegółowych, nie występują cele w ujęciu operacyjnym.

Również treści nauczania są znacznie zróżnicowane. Autorzy większości programów grupują treści wg wyznaczonej przez podstawę programową tematyki, rozbudowując zamieszczone w niej hasła. Zapis haseł wskazuje na mechanistyczne i tradycyjne ujęcie treści, np.: Zasady pracy zespołowej. Kierowanie i podejmowanie decyzji. Funkcjonowanie rynku i gospodarki rynkowej.

Dostrzec można brak aktualnych tematów związanych z nowoczesnym zarządzaniem firmą, słabo wyeksponowane zostały wyzwania stojące przed polską gospodarką, szanse i zagrożenia ze strony gospodarki wolnorynkowej, zjawiska patologiczne w gospodarce wysokie bezrobocie, korupcja (Konarzewski 2004).

Brak jest ujęcia treści wg problemów, które w sposób najwłaściwszy oddałyby istotę tej tematyki oraz zerwały z zasadą podporządkowania treści nauczania prezentacji dorobku naukowego wybranej dyscypliny naukowej, w tym przypadku ekonomii.

Struktura programów nauczania tego przedmiotu na ogół ma cechy układu liniowego, nie uwzględnia się zbyt często w nich korelacji międzyprzedmiotowej. Uczniowie z niektórymi zagadnieniami spotykają się na innych przedmiotach, np. geografii, wiedzy o społeczeństwie, historii zarówno w gimnazjum, jak i szkole ponadgimnazjalnej.

Nasuwa się więc refleksja, że dobór celów i treści kształcenia do podstawy programowej i programu nauczania z podstaw przedsiębiorczości nie może odbywać się na drodze dobrowolności. Wymaga się przestrzegania kolejności etapów postępowania oraz przyjęcia istniejących w dydaktyce ogólnej kryteriów ich i doboru i układu (ryc. 1). 
Ryc. 1 Etapy doboru celów i treści nauczania do przedmiotu podstawy przedsiębiorczości

- analiza dokumentów międzynarodowych i państwowych oraz potrzeb społecznych warunkujących cele i kryteria doboru;

/strategia edukacyjna dla Polski do 2020 r., strategia edukacyjna UE, strategia społeczeństwa informacyjnego/

- określenie celu /ów/ globalnych, wynikających z istniejących wyzwań międzynarodowych i przyjętych rozwiązań;

/przygotowanie uczącego się do życia zawodowego i funkcjonowania w tworzącym się społeczeństwie wiedzy zorientowanym na wartości i człowieka/

- określenie celów naczelnych, które są pochodną celu globalnego i wynikają z przyjętych rozwiązań systemowych i aktów prawnych systemu szkolnego w naszym kraju; otwarcie na środowisko i świat, powszechny dostęp do nauczania, jakość i efektywność procesu kształcenia, ustawiczne uczenie się, uczenie się na odległość (elearning)/

- ustalenie celów kierunkowych, odpowiadających edukacji z podstaw przedsiębiorczości

/nastawienie na rozwój i zmiany, mobilność ucznia i wspieranie inwestowania w jednostkę, dokonywanie własnych wyborów życiowych oraz podejmowania różnych decyzji zorientowanych na wartości, zbliżenie szkół i przedsiębiorstw/

- transformacja celów kierunkowych i rozpisanie ich na poszczególne etapy ksztalcenia;

/ustalenie zestawu podstawowych pojęć i zakresu tematyki na poszczególne etapy nauczania/

- dobieranie i układanie treści do poszczególnych klas z uwzględnieniem kryteriów: pedagogiczno-psychologicznych, merytoryczno-dydaktycznych i organizacyjnych

Źródło: Opracowanie własne na podstawie: Bailey, Fox (1996), Arends (1994), Cichy (2002), Piskorz (1997).

\section{TEORETYCZNE KRYTERIA DOBORU TREŚCI NAUCZANIA DO PODSTAWY PROGRAMOWEJ I PROGRAMU NAUCZANIA Z PODSTAW PRZEDSIĘBIORCZOŚCI}

Opracowując podstawy programowe do przedmiotu podstawy przedsiębiorczości należy się zaznajomić ze współczesnymi zadaniami stawianymi edukacji zawartymi w opracowanej Strategii edukacyjnej dla Polski do 2020 r., Białej Księdze Komisji Europejskiej „Nauczanie-uczenie się” oraz wynikami badań nad osiągnięciami uczniów w zakresie umiejętności niezbędnych do funkcjonowania w społeczeństwie.

W dokumentach tych wskazano na potrzebę istotnych zmian w kształceniu młodego człowieka. Podkreśla się konieczność przygotowania ucznia do życia zawodowego i funkcjonowania w tworzącym się społeczeństwie wiedzy zorientowanym na wartości i człowieka. Realizację tego postulatu upatruje się m.in.: poprzez powszechny dostęp do edukacji, wykorzystanie możliwości współczesnej techniki w kształceniu-nauczaniu na odległość (elearning) oraz otwarcie na środowisko i świat. 
Prowadzone badania osiągnięć uczniów wskazują na braki systemów edukacyjnych w zakresie przygotowania młodych ludzi do funkcjonowania w społeczeństwie. Braki te dotyczą umiejętności, tzw. kluczowych - potrzebnych do efektywnego i pełnego uczestnictwa w życiu społecznym i zawodowym oraz politycznym. Do tych umiejętności zalicza się: rozumienie tekstu, myślenie naukowe, myślenie matematyczne (Białecki, Haman 2001).

Zarysowując koncepcję podstaw programowych powinno się także uwzględnić potrzeby społeczne i gospodarcze oraz możliwości intelektualne młodzieży, do której jest ona adresowana.

Zapis celów i treści nauczania w podstawie programowej powinien być na tyle szczegółowy, aby nie prowadził do zbyt dużej dowolności w jej interpretacji. Zbyt ogólnie zapisane hasła prowadzą do dużego zróżnicowania treści w poszczególnych programach nauczania tego przedmiotu.

Z kolei przystępując do opracowania programu nauczania $\mathrm{z}$ podstaw przedsiębiorczości należy się gruntownie zaznajomić z ministerialnymi podstawami programowymi oraz współczesnymi tendencjami w nauczaniu przedmiotów społecznych.

W oparciu o te informacje można przystąpić do zarysowania koncepcji opracowywanego programu. Należy ustalić jego powiązania z innymi przedmiotami na poziomie gimnazjum i szkoły ponadgimnazjalnej oraz przyjąć kryteria doboru treści i ich układ w programie, uzasadniając dokonany wybór. Wśród kryteriów wyboru treści nauczania należy uwzględnić:

- kryteria pedagogiczno-psychologiczne (potrzeby społeczno-gospodarcze, podstawa programowa, współczesne tendencje w nauczaniu tej tematyki w Europie i świecie, ogólna koncepcja kształcenia, ciągłość, progresja, rozwój intelektualny);

- kryteria merytoryczno-dydaktyczne (korelacja międzyprzedmiotowa, różnicowanie treści programowych, aktualizacja treści, zainteresowania i motywacja uczniów);

- kryteria organizacyjne (liczba godzin w planie nauczania).

Wydaje się coraz oczywistym wniosek o konieczności kompleksowego rozwiązywania zagadnień programowych przy określaniu celów i treści kształcenia na danym etapie nauczania i udziału poszczególnych przedmiotów w ich realizacji. Jest to sposób do głębszej korelacji międzyprzedmiotowej (spójność synchroniczna), usunięcia z programów drugorzędnych treści, zbędnych powtórzeń, nierównomiernego obciążenia materiałem nauczania w kolejnych klasach. Postulat ten wskazują zarówno teoretycy pedagodzy, jak i nauczyciele praktycy (Konarzewski 2004).

Integracja przedmiotów społecznych daje możliwość wprowadzenie całościowych zagadnień możliwych do rozwiązania wyłącznie wówczas, gdy uczeń będzie posługiwał się wiedzą z geografii, historii, podstaw przedsiębiorczości, wiedzy o społeczeństwie.

Przy obecnym modelu opracowywania programów nauczania, gdzie autorzy ich pracują w izolacji, każdy nad danym przedmiotem, autor programu z podstaw przedsiębiorczości nie jest w stanie skorelować swojego programu z programem geografii, historii, wiedzy o społeczeństwie, ponieważ go nie zna.

Równie ważnym kryterium jest różnicowanie treści programowych uwzględnionych w procesie kształcenia. Na całym świecie nasila się tendencja do brania pod uwagę w nauczaniu indywidualnych uzdolnień i zainteresowań ucznia. Szczególnie dobre warunki dla rozwoju indywidualnych uzdolnień i zainteresowań uczniów stwarzają programy opracowane dla poszczególnych typów szkół: liceum ogólnokształcące, liceum profilowane, technikum, szkoła zawodowa.

Zakres treści nauczania w technikach, liceach profilowanych, szkołach zawodowych powinien pozwolić uczniowi na nabycie umiejętności związanych z aktywnością gospodarczą, którą podejmie po ukończeniu tego typu szkoły. Dlatego wskazane jest wprowadzenie treści dotyczących pozyskiwania środków na prowadzenie własnej działalności gospodarczej, prawa podatkowego, prawa pracy.

Opracowane programy w niewielkim stopniu uwzględniają to kryterium. Jednakowe treści z tej tematyki proponowane są dla szkół różnych typów. 
Po opracowaniu programu wskazane jest przeprowadzenie jego analizy i oceny. Sprawdzić należy zachowanie hierarchii celów kształcenia oraz logiczną strukturę dobranych treści nauczania. Dopiero jednak eksperymentalne sprawdzenie przydatności programu w warunkach szkolnych wykaże jego walory i braki, a szczególnie zainteresowanie uczniów oraz jakość opanowanej wiedzy i umiejętności.

\section{ŹRÓDŁA I LITERATURA}

Arends R., 1994, Uczymy się nauczać. WSiP, Warszawa.

Bailey p., FoxP., 1996, Geography Teacher's Handbook. The Geographical Association.

Białecki I., Haman J., Program Międzynarodowej Oceny Uczniów OECD/PISA. Wyniki Polska - raport z badań, www.ifis.pan.waw.pl

Cichy D., 2002, Programowanie celów i treści edukacji środowiskowej. [w:] Edukacja środowiska - programy, metody, efekty. IBE, Warszawa.

Dziennik Ustaw, Rozporządzenie MENiS nr 14, z dn. 24.04.2002.

Gregorczyk S., Romanowska M., Sopińska A., Wachowiak P., 2002, Przedsiębiorczość bez tajemnic. Program nauczania dla liceum ogólnokształcacego, liceum profilowanego $i$ technikum. WSiP Warszawa.

Komisja Europejska. Biała Księga Nauczania i uczenia się. Wyd. Wyższa Szkoła Pedagogiczna TWP, 1995 Warszawa.

Komorowska H., 1995, Konstrukcja, realizacja i ewaluacja programu nauczania. Wyd. IBE Warszawa.

Korba J., Mistrzak M., Smutek Z., 2003, Podstawy przedsiębiorczości. Program nauczania $w$ zakresie podstawowym dla liceum ogólnokształcacego, liceum profilowanego $i$ technikum. Wyd. Operon, Gdynia.

Makieła Z., Rachwał T., 2002, Podstawy przedsiębiorczości. Program nauczania liceum ogólnoksztatcącego, liceum profilowanego i technikum. Kształcenie ogólne w zakresie podstawowym. Wyd. Nowa Era, Warszawa.

Piskorz S.,(red), 1997, Zarys dydaktyki geografii. PWN, Warszawa.

Uczymy się żyć. Cele Programu OECD/PISA i jego uczestnicy. MEN 2001 Warszawa. 